\title{
Effects of peeling methods on the quality of cubiu fruits
}

\author{
Efeito dos métodos de descasque na qualidade dos frutos de cubiu
}

\author{
Luty Gomez CACERES ${ }^{1}$, Jerusa Souza ANDRADE ${ }^{1 *}$, Danilo Fernandes da SILVA FILHO ${ }^{1}$
}

\begin{abstract}
Cubiu (Solanum sessiliflorum Dunal) is an Amazonian Basin native fruit. Its importance comes from its high contents of pectin. Currently, processing technologies are necessary for the substitution of the traditional system (small crops and small-scale processing) for a larger scale system and thus increase the use of biodiversity and promote the implementation of Local Productive Arrangements of agribusiness in the Amazon. This research aims to evaluate the methods of peeling cubiu. Ripe fruits were divided into lots (150 each) and subjected to the following treatments: immersion in $2.5 \% \mathrm{NaOH}$ boiling solution for 5 minutes, exposure to water vapor, and immersion in water at $96{ }^{\circ} \mathrm{C}$ for $5,10,15$ and 20 minutes. The peel released during heat treatment and immediately removed under running tap water. In the control treatment, the fruits were manually peeled (unheated) with a stainless steel knife. The treatments were evaluated for completeness and ease of peeling, tissue integrity, texture, and peroxidase activity. The immersion in $2.5 \% \mathrm{NaOH}$ boiling solution ( 5 minutes) stood out as the best treatment since it inhibited the enzymatic browning and intensified the natural yellow color of the cubiu fruit and easily and fully peeled the whole fruit more rapidly without damaging its tissues. This treatment was chosen as the most advantageous because it can promote simultaneous peeling and bleaching. Therefore, it is recommended for cubiu industrial processing.

Keywords: Solanum sessiliflorum; boiling water; water vapor; boiling $\mathrm{NaOH}$ solution; blanching; texture.
\end{abstract}

\section{Resumo}

Cubiu (Solanum sessiliflorum Dunal) é um fruto amazônico cujo interesse decorre do alto teor de pectina. Atualmente, tecnologias de processamento são necessárias para a transposição do sistema tradicional (pequeno cultivo e processamento artesanal) para o de escala maior e, assim, aumentar o uso da biodiversidade e viabilizar os Arranjos Produtivos Locais e o agronegócio na Amazônia. Esta pesquisa tem o objetivo de avaliar os métodos para o descascamento do cubiu. Frutos maduros foram divididos em lotes (150 frutos cada) e submetidos aos seguintes tratamentos: imersão em solução (fervente) de $\mathrm{NaOH}$ a 2,5\%, exposição ao vapor de água e imersão em água a $96^{\circ} \mathrm{C}$ por $5,10,15$ e 20 minutos. A casca liberada durante os tratamentos térmicos foi removida sob a água corrente. No controle, os frutos foram descascados (sem aquecimento) com faca de aço inoxidável. Os tratamentos foram avaliados pela totalidade e facilidade do descascamento, integridade dos tecidos, textura e atividade da peroxidase. O tratamento em solução fervente de $\mathrm{NaOH}$ 2,5\% (5 minutos) destacou-se como o melhor tratamento uma vez que inibiu o escurecimento enzimático, intensificou a cor natural amarela do fruto, descascou inteira e facilmente todos os frutos e não danificou a integridade dos tecidos. Este tratamento foi escolhido e recomendado para o processamento industrial do cubiu por promover simultaneamente o descascamento e branqueamento do fruto.

Palavras-chave: Solanum sessiliflorum; água fervente; vapor de água; solução fervente de $\mathrm{NaOH}$; branqueamento; textura.

\section{Introduction}

In the industrial processing of fruits and vegetables, the peeling and bleaching processes are considered pretreatments. The choice of the most appropriate treatment depends on the raw material and necessary attributes for the final product. These processes are important because they influence the yield (and consequently the amount of discarded portion) and quality (appearance, color, texture, and nutritional value) of the product manufactured.

Pretreatments used in the processing of fruits and vegetables such as peeling have great importance in terms of nutritional and economic aspects. The aim of peeling is not only removing the peel but also minimizing the losses related to tissue and nutritional value (GULDAS, 2003). Peeling is used to remove the peel when it is not edible, or even when it is edible, but its presence is undesirable in the final product. The fruits are covered by a layer called peel, skin, cuticle, or pericarp composed of cells that constitute a polymer matrix with intracuticular waxes wrapped in a polymeric skeleton (HOLLOWAY; CUTLER; PRICE-CUTLER, 1982). Fruit peel is the outer skin or the covering of fruits; it has multiple physiological functions and acts as a protective barrier against water loss, nutrient leaching, mechanical damage, and invasion by pathogens (PESCHEL et al., 2007; RAY; STARK, 1998).

The peeling methods are generally classified into: mechanical abrasion, chemical, thermal and enzymatic (BARRY-RYAN; O'BEIRNE, 2000; GULDAS, 2003; PINNAVAIA et al., 2006, 2007; PRETEL et al., 2007). Among the chemical treatments, the $\mathrm{NaOH}$ solution is the most commonly used since it attacks the thin waxy layer of the skin, penetrates in the pores, and hydrolytically degrades the pulp layer adhered to the cuticular tissue (SANTOS, 2008). The temperature and concentration of the solution, as well as the treatment time vary according to

Received 10/6/2010

Accepted 31/1/2012 (004882)

${ }^{1}$ Instituto Nacional de Pesquisas da Amazônia, CP 478, CEP 69060-001, Manaus, AM, Brasil, e-mail: andrade@inpa.gov.br

${ }^{*}$ Corresponding author

http://dx.doi.org/10.1590/S0101-20612012005000039 
the fruit, and are important aspects for peeling efficiency. The effectiveness of peeling with caustic soda depends upon the cultivar used and fruit maturity. In overripe fruits, peeling with caustic soda causes substantial loss of appearance and tissue damage (GULDAS, 2003). These damages were observed in the cubiu fruit at the overripe stages (GOMEZ CACERES, 2010).

Bleaching is used to inactivate enzymes (peroxidase and polyphenoxidase) whose activities may lead to undesirable reactions responsible for enzymatic browning and off-taste. (FREITAS; FRANCELIN; HIRATA, 2008; LUIZ; HIRATA; CLEMENTE, 2007). These enzymes are associated with the loss of quality and thus need to be inactivated. Generally, immersion in hot water or water vapor exposure for a short time is used. However, with regard to peroxidase inactivation, the treatment at $75-80^{\circ} \mathrm{C}$ for 10 minutes caused $85 \%$ of inactivation in concentrated apple juice (VALDERRAMA; MARANONI; CLEMENTE, 2001) and only $34 \%$ in avocado pulp (LUIZ; HIRATA; CLEMENTE, 2007). On the other hand, in sliced cubiu fruit treated for only one minute at $90^{\circ} \mathrm{C}$ was sufficient to reduce peroxidase activity by $80-90 \%$ (OLIVEIRA, 2002).

Peeling and bleaching are necessary for cubiu industrialization. Cubiu (Solanun sessiliflorum Dunal), a native fruit of the Amazon, is easy to cultivate due to its high productivity and rusticity (SILVA FILHO et al., 2005) to its nutritional, medicinal, and technological properties (PIRES et al., 2006). Traditionally, cubiu is used in preparations of sweet-tasting foods (juices, jellies, jams, and preserves) as well as in salty foods (sauces and salads and as ingredient of meat and fish stews) (ANDRADE; COELHO; SILVA FILHO et al., 2010). The great interest in industrialization comes from its pulp yield and high pectin content (ANDRADE; COELHO; SILVA FILHO et al., 2010; ANDRADE JÚNIOR, 2006), as well as the beneficial effect of the cubiu in the metabolism of the lipids and glucose (PARDO, 2004). However, bleaching (used to prevent enzymatic browning) and peeling are required to produce processed fruit products (OLIVEIRA, 2002). In order to gather information to the expansion of the LPAs and the implementation of agro-industries in the Amazon, this research aims to test a method to simultaneously obtain the peeling and enzymatic inactivation of cubiu fruits.

\section{Material and methods}

Cubiu fruits were harvested at ripe stage from plants grown at Ariaú Experimental Station, and the experiments were conducted at the Food Technology Department; both belong to the National Institute for Amazon Research (INPA). The fruits underwent selection (disposal of damaged and over-ripe), washing, and sanitization by immersion for 15 minutes in a $0.02 \%$ sodium hypochlorite solution and rinse under tap water.

\subsection{Fruit peeling}

In preparation for the peeling process, the fruits were divided into lots (150 each) and subjected to the following treatments: immersion in $2.5 \% \mathrm{NaOH}$ (boiling) solution (T1), exposure at water vapor (T2), and immersion in water at $96^{\circ} \mathrm{C}(\mathrm{T} 3)$ for $5,10,15$, and 20 minutes The detached peel was immediately removed by hand friction under running tap water. The internal cooling of the fruit was completed by immediate immersion in an ice-water bath. The control (T0) fruits (unheated) were manually peeled with stainless steel knife.

\subsection{Peeling efficiency assessment}

Peeling efficiency was assessed in each fruit considering the completeness and ease of peeling. The fruits that were partially peeled or those that demanded a drastic friction to remove the peel fragments still attached to the pulp were not considered. The results were expressed in percentages considering the number (n) of peeled fruit and the total number of fruits used in each treatment.

\subsection{Tissue integrity evaluation}

Tissue integrity was evaluated using sensory analysis (touch and vision). Fruit that were partially peeled or had damaged surface were discarded; only those with firm texture, resistant to the touch, smooth surface, and no damaged tissue were considered. The results were expressed in percentages.

\subsection{Texture assessment}

The fruits from in the treatments that were not selected in the first step of this study (those that were damaged or were not completely peeled) were not used in instrumental texture analysis either. Samples of fruits from T0 (control, manually peeled), T1 (5 minutes), T2, and T3 (20 minutes) treatments were evaluated.

Rectangular samples $(3 \times 1 \times 1 \mathrm{~cm})$ were obtained from the mesocarp of the peeled fruits and arranged with the inner surface facing up. Texture was measured using a texturometer (Stable Micro Systems Texture Analyzer, model TA-XT2). The operating conditions were as follows: cylindrical probe $(40 \mathrm{~mm})$; distance of $4 \mathrm{~mm}$; speed of 2 (pre-test), 1 (test), and 5 (post-test) $\mathrm{mm} / \mathrm{s}$. Texture analysis was performed with three repetitions and 20 readings for each repetition. The data were expressed in Newton $(\mathrm{N})$.

\subsection{Peroxidase activity}

Peroxidase activity was determined according to the method described by Lee, Penessi and Dickson (1984) with modifications (OLIVEIRA, 2002). The extraction process was carried out under cooling temperature using an ice water bath. The materials and solutions were previously cooled. For the extraction, $2 \mathrm{~g}$ of the mesocarp with $50 \mathrm{mM}$ sodium phosphate buffer $(\mathrm{pH} 7.0)$ and $0.1 \%$ of polyvinylpyrrolidone were triturated in a porcelain mortar. After filtration and centrifugation (refrigerated) for 5 minutes at 3,500 rpm, the supernatant was transferred to Eppendorf tubes and kept in an ice bath until use.

The following reaction mixture was used for peroxidase activity: $3 \mathrm{~mL}$ of $50 \mathrm{mM}$ sodium phosphate buffer ( $\mathrm{pH} 7.0$ ), $124 \mu \mathrm{L}$ of $20 \mathrm{mM}$ guaiacol, $45.3 \mu \mathrm{L}$ of $30 \%(\mathrm{w} / \mathrm{v}) \mathrm{H}_{2} \mathrm{O}_{2}$, and $100 \mu \mathrm{L}$ of the enzyme extract. The reaction was conducted at $40^{\circ} \mathrm{C}$ for five minutes, and the absorbance was read at $420 \mathrm{~nm}$ 
in a Spectrophotometer. Enzymatic activity (U/g/minute) was defined as the amount of enzyme required to increase 0.0001 absorbance units per minute. The reduction in enzyme activity was expressed as percentage.

\subsection{Statistical analysis}

The evaluation of the peeling process was carried out according to a completely randomized design in $3 \times 4$ factorial scheme $(\mathrm{NaOH}$ solution, water vapor, and boiling water for 5 , 10,15 , and 20 minutes) with five repetitions; each repetition was composed of 10 fruits. The texture analysis was performed with three repetition and completely randomized design.

The data obtained from the peeling and texture assays were subjected to analysis of variance, and when $\mathrm{F}$ was significant, the Tukey test of means was applied with $5 \%$ of probability using ASISTAT $^{\circ}$ software, version 7.2 (SILVA; AZEVEDO, 2002).

\section{Results and discussion}

\subsection{Peeling}

The results show the superiority of chemical peeling (Figure 1). The 5-minute treatment with $2.5 \% \mathrm{NaOH}$ solution was sufficient to easy and entirely remove the peel of all fruits. The 20 -minute treatment with water at $96{ }^{\circ} \mathrm{C}$ and water vapor showed values of 70 and $57 \%$, respectively. The others $(5,10$, and 15 minutes) were insufficient in the treatments T2 and T3. The conditions used in the chemical peeling process vary. Using $\mathrm{NaOH}$ solutions, four minutes $\left(10 \%\right.$ at $\left.80{ }^{\circ} \mathrm{C}\right)$ were needed for the peeling of yacon roots (SILVA et al., 2010), 4 minutes $\left(15 \%\right.$ at $\left.95{ }^{\circ} \mathrm{C}\right)$ for kiwi (GULDAS, 2003), 5 minutes $(12.72 \%$ at $\left.90{ }^{\circ} \mathrm{C}\right)$ for potatoes, and 60 seconds $\left(9 \%\right.$ at $\left.90{ }^{\circ} \mathrm{C}\right)$ for tomato (BAYINDIRLI, 1994). The concentrations recommended were $\mathrm{NaOH}$ solution at $15 \%$ for peach (MENDONÇA et al., 2005) and $6 \%$ for tomato (SANTOS, 2008). These results showed that the effectiveness of the peeling with $\mathrm{NaOH}$ solution depends on the time, concentration, and temperature.

In addition to the quantity of peeled fruit, the easiness to remove the peel, which was previously released during the heat treatments, was also observed. During the treatment, the peel wrinkled gradually evidencing internal inner layer hydrolysis, but the peel remains semi- detached from the fruit without rupturing (without tearing). When the fruit was removed from the heat and exposed to tap water, the peel was rapidly and easily removed under running tap water (insufficient for internal cooling), and the fruit was immediately immersed in an ice water bath. The other treatments (water vapor and boiling water) presented an incomplete skin detachment requiring hand friction under running tap water to finish the peeling process. Generally, areas with incomplete peeling were located around the peduncle indicating tissular differences. Since the objective was to avoid using a knife, manual reprocessing was a negative aspect of the treatments with water vapor and boiling water.

Peeling was easy and complete in the treatment with $2.5 \% \mathrm{NaOH}$ solution for 5 minutes. The fruit showed good appearance; pulp surface completely smooth and shiny. The beneficial effect of heat was evident when compared with the control treatment (unheated), especially the chemical peeling (5 minutes). Besides preventing enzymatic browning, it intensified the yellow color and a high brightness surface was

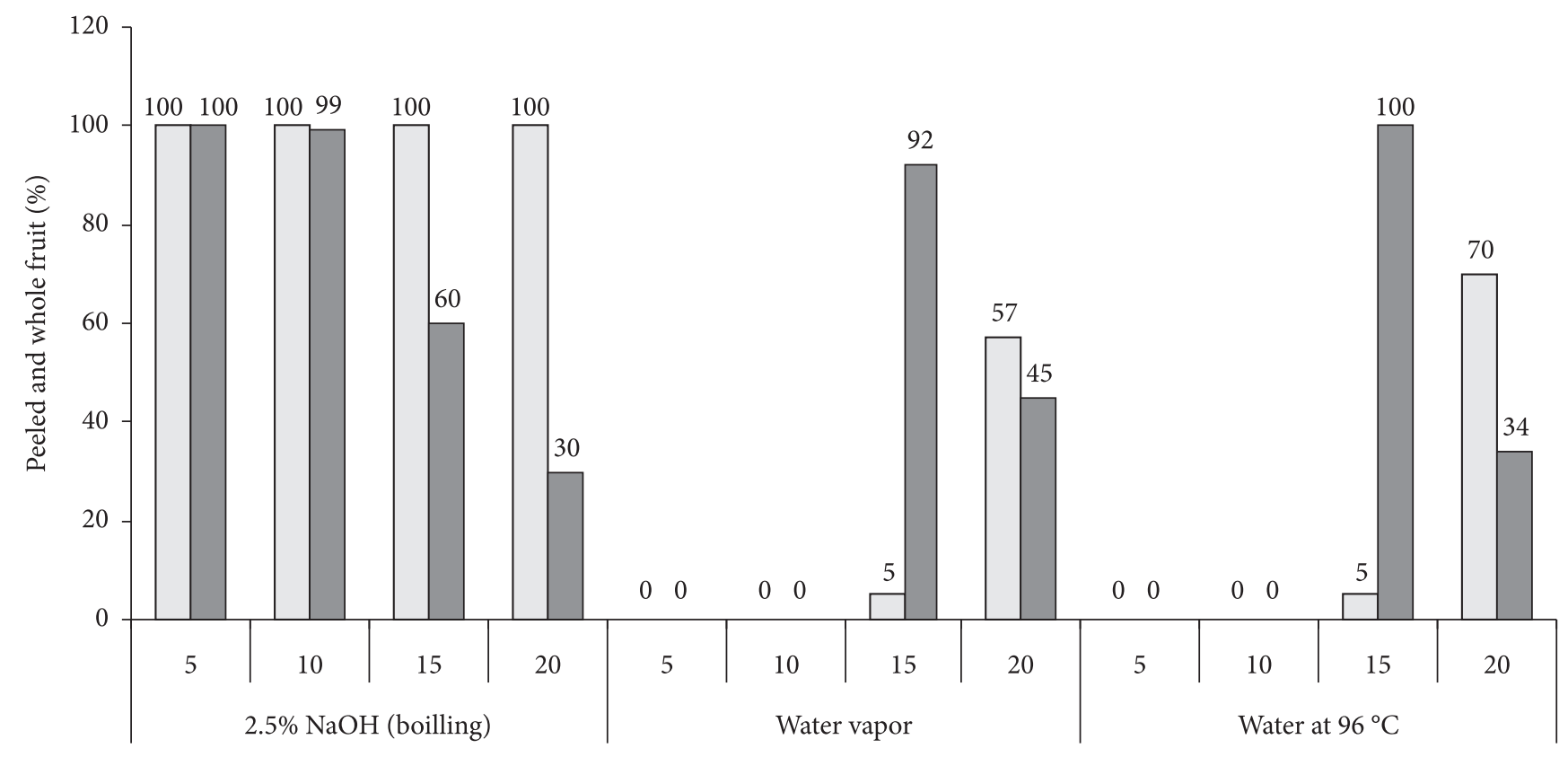

Time (minutes) and peeling method

$\square$ Peeled fruit $\square$ Whole fruit

Figure 1. Effect of the peeling treatments on the quantities of peeled and whole cubiu (Solanum sessiliflorum Dunal) fruits. 
developed. The others showed uneven surfaces in areas where the peel had not been fully detached during the heat treatment. Under the longest time of heat exposure (20 minutes), for all treatments (T1, T2, and T3), the pulp presented softened texture. Some fruits showed damaged tissues and developed a cooked aspect. These fruits were not accounted for and were discarded. Nicks and cut marks were left by the knife used in the T0 treatment (control) on the peeled surface. Since appearance and firmness of the fruit flesh are important features for some industrialized products, the combination of $2.5 \% \mathrm{NaOH}$ solution with the lowest treatment time (five minutes) stood out as the best treatment for the cubiu fruit.

\subsection{Tissue integrity}

The integrity of the peeled fruit was also evaluated. The time should be minimal to avoid softening, disintegration, or cooking. This precaution is important, especially if other heating processes will used in the following steps and if the processed product (jam or preserve) requires intact tissues.

The results presented in Figure 1 show that in the chemical treatment all fruits were peeled, but it was only under the shortest time of heat exposure that tissue integrity was maintained. In the same solution with 15 and 20 minutes, tissue integrity decreased to 60 and 30\%, respectively. T2 (water vapor) and T3 (boiling water) were not effective. The longest time of treatment (20 minutes) affected the integrity of all fruits. The undesired aspects were: cooking, disintegration, translucency, water absorption, and wet appearance (moistened). Although this evaluation considered only the fully peeled fruit, it was observed that with the 20-minute treatment, some fruits in treatment T2 (17 units) and T3 (23 units) showed an incomplete peeling and presented softened aspect.

Since the variance analysis showed a significant difference in the treatments and the interactions between variables (treatment/time), the analysis of these interactions show the average (in percent) of the peeling in relation to the different methods and times used (Table 1). T1 differed significantly from the others. Under the lowest times of heat exposure $(5,10$, and 15 minutes), T2 and T3 were not significantly different. In order to choose the best treatment, the following aspects were considered: completeness and ease of peeling, tissue integrity, and appearance and texture changes. T1 (5 minutes) was the best peeling treatment to preserve similarity with the fresh fruit.

\subsection{Texture}

The firm texture $(26.93 \mathrm{~N})$ of the fresh cubiu (unheated fruit in T0) was softened by the action of heat during the peeling process in all treatments. For the fruits in treatment T1 (5 minutes) the compression force (average) was $17.58 \mathrm{~N}$ $(175.8 \mathrm{kPa})$. The greatest softening was observed in T2 $(6.64 \mathrm{~N})$ and T3 $(5.48 \mathrm{~N})$, both under 20 minutes of heat exposure (Table 2). Heat treatment diminishes the texture integrity of processed vegetables (NI; LIN; BARRETT, 2005). During the peeling of fruits, the loss of firmness should be minimal when they are destined for preserves and pickles since subsequent heat treatments are also employed. However, for dehydrated fruits (osmotic dehydration), the loss of firmness during the peeling stage could be neglected because the concomitant process of water removal and solutes incorporation in the subsequent osmotic dehydration can return the product tissue firmness (GOMEZ CACERES, 2010; FREITAS, 2011).

T1 (5 minutes of heat exposure) showed the best correlation (average values) between firmness (compression force), whole fruit, and tissue integrity (Figure 2). The opposite was observed

Table 1. Effect of the peeling methods and time on the quantity of the peeled fruits.

\begin{tabular}{cccc}
\hline \multirow{2}{*}{$\begin{array}{c}\text { Time } \\
\text { (minutes) }\end{array}$} & \multicolumn{3}{c}{ Peeling methods } \\
\cline { 2 - 4 } & $2.5 \% \mathrm{NaOH}$ (Boiling) & Water vapor & Water $\left(96^{\circ} \mathrm{C}\right)$ \\
\hline 5 & $100 \mathrm{aA}$ & $0 \mathrm{bB}$ & $0 \mathrm{bB}$ \\
10 & $100 \mathrm{aA}$ & $0 \mathrm{bB}$ & $0 \mathrm{bB}$ \\
15 & $100 \mathrm{aA}$ & $5 \mathrm{bB}$ & $5 \mathrm{bB}$ \\
20 & $100 \mathrm{aA}$ & $57 \mathrm{cA}$ & $70 \mathrm{bA}$ \\
\hline
\end{tabular}

Means of five repetitions followed by the same capital letters in the column and by the same minor letters in the line are not statistically different $(\mathrm{p} \leq 0.05$, Tukey test).

Table 2. Firmness of the cubiu fruits peeled using different methods.

\begin{tabular}{lcccc}
\hline \multicolumn{1}{c}{ Treatments } & $\begin{array}{c}\text { Distance } \\
(\mathrm{mm})\end{array}$ & $\begin{array}{c}\text { Firmness } \\
(\mathrm{N})\end{array}$ & S.D. & $\begin{array}{c}\text { C.V. } \\
(\%)\end{array}$ \\
\hline Manual peeling (with knife) & 3.32 & $26.93 \mathrm{a}$ & 0.73 & 2.72 \\
2.5\% NaOH boiling (5 minutes) & 4.03 & $17.58 \mathrm{~b}$ & 0.46 & 2.63 \\
Water vapor (20 minutes) & 3.84 & $6.64 \mathrm{c}$ & 0.29 & 4.43 \\
Water at $96^{\circ} \mathrm{C}$ (20 minutes) & 3.74 & $5.48 \mathrm{c}$ & 0.23 & 4.16 \\
\hline
\end{tabular}

Means of three repetitions followed by the same letters are not statistically different ( $\mathrm{p} \leq 0.05$, Tukey test).

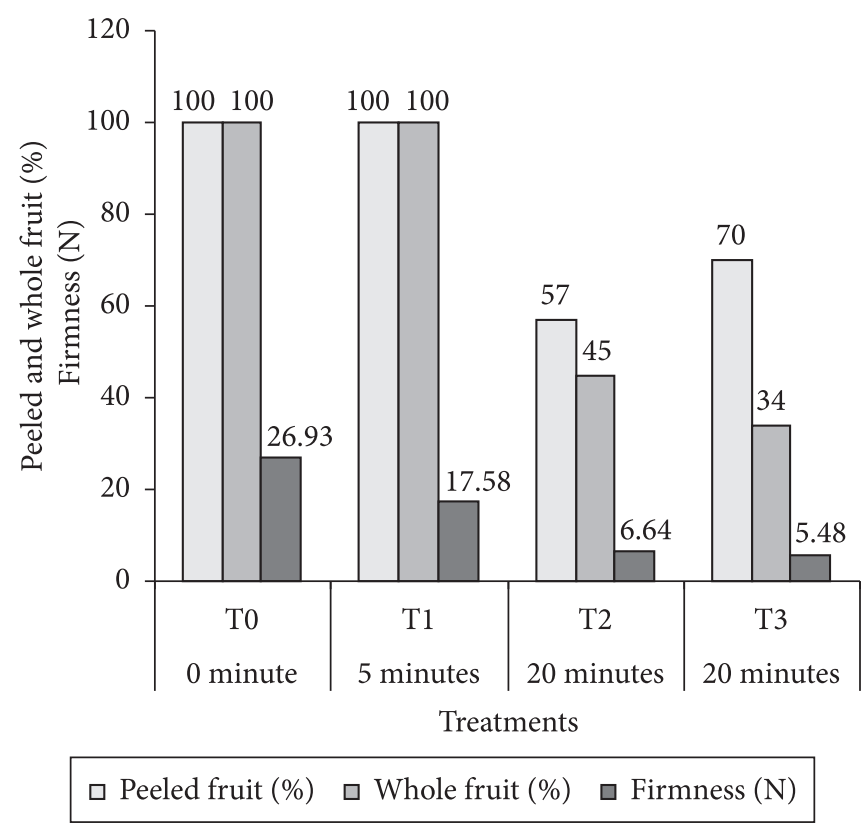

Figure 2. Effect of the peeling methods on the quantity, integrity, and firmness of peeled cubiu (Solanum sessiliflorum Dunal) fruits; (T0) peeled with knife (control); (T1) immersion in $2.5 \% \mathrm{NaOH}$ (boiling) solution; (T2) exposure to water vapor; (T3) immersion in water at $96^{\circ} \mathrm{C}$. 
in the treatments T2 and T3. Usually, besides the beneficial effects of heat treatment during peeling and/or bleaching of fruits and vegetables, it causes an undesirable softening. In peppers, heat treatment (one minute in $1 \% \mathrm{NaCl}$ solution at $100^{\circ} \mathrm{C}$ ) caused softening of the texture (DUTRA et al., 2007). Softening was observed during postharvest shelf life of cubiu stored under ambient conditions. On day 6 , when the fruits were apparently firm, firmness corresponded to $532.30 \mathrm{kPa}$ for skin and $117.42 \mathrm{kPa}$ for pulp. Skin and pulp resistance decreased with increasing storage time and reached reductions corresponding to 62.98 and $85.9 \%$ from harvest to the end of day 15 (SILVA; ROCHA; SALOMÃO, 2011).

Statistical analysis showed significant difference between means (texture) of manual peeling (unheated fruit), chemical peeling (better performance), and others (Table 1). The texture of fruits treated with chemical peeling remained closer to that of fresh fruit in the treatment T0 (unheated). The other treatments which obtained an acceptable peeling (20 minutes in water vapor and boiling water) showed no significant difference between them.

\subsection{Enzymatic activity}

The peroxidase activity of the fresh fruit in the treatment T0 (peeling with the knife) was lower than that measured in fresh cubiu (without peeling) (OLIVEIRA, 2002). Cubiu is a fruit that requires heat treatment to prevent enzymatic browning, and, consequently, to preserve the natural color. The heat treatment caused simultaneous peeling and bleaching. Treatment with $\mathrm{NaOH}$ solution (chemical peeling) and heating for just 5 minutes was enough for the peeling and for preventing enzymatic browning. At the same time, it caused 92.6\% reduction in the peroxidase activity. During the longest time of heat exposure (20 minutes), there was peeling and total enzymatic inactivation (Table 3 ), but it resulted in large quantities of fruits with undesirable and softened texture (damaged) (Figure 1).

The reduction of enzyme activity compared to the control treatment was $92.6 \%$ in the chemical peeling and $100 \%$ for the others regardless of the treatment (Table 3). These results are different from those obtained with crude enzyme extract (polyphenoloxidase and peroxidase) from guava, in which time $\left(0-10\right.$ minutes) and temperature $\left(60-80{ }^{\circ} \mathrm{C}\right)$ influenced the enzyme activity but not enough to achieve total inactivation (ZANATTA; ZOTARELLI; CLEMENTE, 2006). However, Brito et al. (2005) obtained thermal inactivation (without regeneration) of pineapple peroxidase (IAC Gomo-de-mel and IAC-1 clone) treated for two minutes at $90^{\circ} \mathrm{C}$.

Table 3. Peroxidase activity in cubiu fruits peeled using different methods.

\begin{tabular}{lc}
\hline \multicolumn{1}{c}{ Treatments } & $\begin{array}{c}\text { Enzymatic activity } \\
(\mathrm{U} / \mathrm{g} / \mathrm{min})\end{array}$ \\
\hline Manual peeling (with knife) & 678 \\
Sodium hydroxide $2.5 \%$ (boiling) for 5 minutes & 50 \\
Water vapor for 20 minutes & 0 \\
Water at $96^{\circ} \mathrm{C}$ for 20 minutes & 0 \\
\hline
\end{tabular}

In the treatments with boiling water and water vapor, peeling occurred only under the longest time of exposure (20 minutes). The appearance of the cooked fruits and the absence of peroxidase activity confirmed that the heat exposure of 20 minutes (on heat) was excessively long. Considering the statements that a residual activity between 3 and $10 \%$ is normal, and that the absence of enzyme activity is generally associated with the risk of cooking the fruit (GÜNES; BAYINDIRLI, 1993), the use of $2.5 \% \mathrm{NaOH}$ (boiling) solution for 5 minutes, with simultaneous peeling and bleaching is recommended as pre-treatment to industrial processing of the cubiu.

The peroxidase (OLIVEIRA, 2002) and polyphenoloxidase (ANDRADE; COELHO; SILVA FILHO et al., 2010) activities are responsible for enzymatic browning in cubiu fruit. After cutting, peeling, and especially crushing (for processing of the pulp), the fruit color changes from light yellow to dark brown. The fruits in the treatment T0 exhibited a yellow color only for a short time. The fruits in the other treatments (longer time of heat exposure) showed no darkening. The color of the fruits in the treatment T1 ( 5 minutes) changed from light yellow to dark yellow. This change was more significant than that presented by the other treatments (boiling water and water vapor). Therefore, chemical peeling for 5 minutes, effectively peeled the fruit, prevented enzymatic browning, and intensified the yellow natural color of the fruit.

\section{Conclusion}

Under the experimental conditions, the treatments with water vapor and boiling water did were not effective. The longest time of heat exposure caused tissue damage in all treatments. The $2.5 \% \mathrm{NaOH}$ (5 minutes) solution stood out as the best treatment since it inhibited the enzymatic browning and intensified the natural yellow color of the cubiu fruit and easily and fully peeled the whole fruit more rapidly, without damaging its tissues. This treatment was chosen as the most advantageous because it can promote simultaneous peeling and bleaching. The employment of the boiling solution of $2.5 \% \mathrm{NaOH}$ for 5 minutes is recommended for cubiu industrial processing.

\section{Acknowledgements}

The authors are grateful to CAPES and CNPq for the research scholarships granted to Luty GOMEZ CACERES and Jerusa ANDRADE, respectively, and to FINEP for the partial funding of this research.

\section{References}

ANDRADE, J. S; COELHO, E. G.; SILVA FILHO, D. F. Postharvest conservation of cubiu (Solanum sessiliflorum Dunal) fruits in response to passive modified atmosphere associated with refrigeration. Acta Horticulturae, v. 864, p. 439-444, 2010.

ANDRADE JÚNIOR, M. C. Mudanças dos índices físico-químicos e toxicológicos de frutos de cubiu (Solanum sessiliflorum Dunal) em diferentes estádios de maturação. 2006. 112 f. Dissertação (Mestrado em Ciência de Alimentos)-Universidade Federal do Amazonas, Manaus, 2006. 
BARRY-RYAN, C.; O'BEIRNE, D. Effects of peeling methods on the quality of ready-to-use carrots slices. International Journal of Food Science and Technology, v. 35, n. 2, p. 234-254, 2000. http://dx.doi. org/10.1046/j.1365-2621.2000.00335.x

BAYINDIRLI, L. Mathematical analysis of lye peeling of tomatoes. Journal of Food Engineering, v. 23, p. 225-231, 1994. http://dx.doi. org/10.1016/0260-8774(94)90088-4

BRITO, C. A. K. de et al. Características da atividade da peroxidase de abacaxis (Ananas comosus (L.) Merrill) da cultivar gomo-de-mel e do clone IAC-1. Ciência e Tecnologia de Alimentos, v. 25, n. 2, p. 244-249, 2005.

DUTRA, A. et al. Cinética da degradação da textura de pimentas em conserva. Boletim Centro Pesquisa Processamento de Alimentos, v. 25, n. 2, p. 267-274, 2007.

FREITAS, A. A.; FRANCELIN, M. F.; HIRATA, G. F. Atividades das enzimas peroxidase (POD) e polifenoloxidase (PPO) nas uvas das cultivares benitaka e rubi e em seus sucos e geléias. Ciência e Tecnologia de Alimentos, v. 28, n. 1, p. 172-177, 2008. http://dx.doi. org/10.1590/S0101-20612008000100025

FREITAS, F. M. O. Obtenção do cubiu (Solanum sessiliflorum Dunal) em passa por métodos combinados. 2011. $116 \mathrm{f}$. Tese (Doutorado em Biotecnologia)-Universidade Federal do Amazonas, Manaus, 2011.

GOMEZ CACERES, L. D. C. P. Otimização da desidratação osmótica do fruto do cubiu (Solanum sessiliflorum Dunal) utilizando solução ternária. 2010. 86 f. Dissertação (Mestrado em Agricultura no Trópico Úmido)-Instituto Nacional de Pesquisas da Amazônia, Manaus, 2010.

GULDAS, M. Peeling and the physical and chemical properties of kiwi fruit. Journal of Food Processing and Preservation, v. 27, n. 4, p. 271-284, 2003. http://dx.doi.org/10.1111/j.1745-4549.2003. tb00517.x

GÜNES, B.; BAYINDIRLI, B. Peroxidase and lipoxygenase inactivation during blanching of green beans, green peas and carrots. Lebensmittel-Wissenschaft und Technologie, v. 26, p. 406-410, 1993. http://dx.doi.org/10.1006/fstl.1993.1080

HOLLOWAY, P. J.; CUTLER, D. F.; PRICE-CUTLER. Structure and histochemistry of plant cuticular membranes. London: Academic Press, 1982. v. 10, p. 1-32. (Linnean Society Symposium Series).

LEE, C. Y.; PENESSI, A. P.; DICKSON, M. H. Characterization of the cauliflower peroxidases isoenzyme. Journal of Agriculture and Food Chemistry, v. 32, n 1, p. 18-21 1984. http://dx.doi.org/10.1021/ jf00121a005

LUİZ, R. C.; HIRATA, T. A.; CLEMENTE, E. Cinética de inativação da polifenoloxidase e peroxidase de abacate (Persea americana MILL.). Ciência Agrotecnologia, v. 31, n. 6, p. 1766-1773, 2007.

MENDONÇA, C. R. B. et al. Características sensoriais de compotas de pêssego light elaboradas com sucralose e acesulfame-k1. Ciência e Tecnologia de Alimentos, v. 25, n. 3, p. 401-407, 2005. http:// dx.doi.org/10.1590/S0101-20612005000300002

NI, L; LIN, D.; BARRETT, D. M. Pectin methylesterase catalyzed firming effects on low temperature blanched vegetables. Journal of Food Engineering, v. 70, n. 4, p. 546-556, 2005. http://dx.doi. org/10.1016/j.jfoodeng.2004.10.009

OLIVEIRA, D. A. Caracterização bioquímica da peroxidase e efeito do tempo de branqueamento na qualidade e aceitabilidade da polpa de cubiu (Solanum sessiliflorum Dunal). 2002. $100 \mathrm{f}$. Dissertação (Mestrado em Ciência de Alimentos)-Universidade Federal do Amazonas, Manaus, 2002.

PARDO, M. A. S. Efecto de Solanum sessiliflorum Dunal sobre El metabolismo lipídico y de la glucosa. Ciencia e Investigación, v. 7, n. 2, p. 43-48, 2004.

PESCHEL, S. et al. Composition of the cuticle of developing sweet cherry fruit. Phytochemistry, v. 68, n. 7, p. 1017-1025, 2007. PMid:17328933. http://dx.doi.org/10.1016/j.phytochem.2007.01.008

PINNAVAIA, S. et al. Enzyme-peeling of Valencia oranges for freshcut slices. Proceedings of the Florida State Horticultural Society, v. 119, p. 335-339, 2006.

PINNAVAIA, S. et al. Flavor and other quality factors of enzymepeeled oranges treated with citric acid. HortScience, v. 42, n. 7 , p. 1644-1650, 2007.

PIRES, A. M. B. et al. Caracterização e processamento de cubiu (Solanum sessiliflorum). Revista Ceres, v. 53, n. 307, p. 309-316, 2006.

PRETEL, M. T. et al. Obtaining fruit segments from a traditional Orange variety (Citrus sinensis (L.) Osbeck cv. Sangrina) by enzymatic peeling. European Food Research and Technology, v. 225 , n. 5-6, p. 783-788, 2007. http://dx.doi.org/10.1007/s00217006-0482-y

RAY, A. K.; STARK, R. E. Isolation and molecular structure of an oligomer produces enzymatically from the cuticle of lime fruit. Phytochemistry, v. 48, n. 8, p. 1313-1320, 1998. http://dx.doi. org/10.1016/S0031-9422(97)00859-5

SANTOS, E. M. Secagem de tomates inteiros submetidos a descascamento químico. 2008. 83 f. Dissertação (Mestrado em Engenharia e Ciências de Alimentos)-Universidade Estadual Paulista, São Jose do Rio Preto, 2008.

SILVA, D. F. P.; ROCHA, R. H. C.; SALOMÃO, L. C. C. Postharvest quality of cocona (Solanum sessiliflorum Dunal) stored under ambient condition. Revista Ceres, v. 58, n. 4, p. 476-480, 2011.

SILVA. E. B. et al. Otimização do descascamento químico de raízes do yacon (Polymnia sonchifolia Poepp). Ciência e Agrotecnologia, v. 34, n. 5, p. 1301-1305, 2010.

SILVA, F. A. S.; AZEVEDO, C. A. V. Versão do programa computacional Assistat para o sistema operacional Windows. Revista Brasileira de Produtos Agroindustriais, v. 4, n. 1, p. 71-78, 2002.

SILVA FILHO, D. F. et al. Caracterização e avaliação do potencial agronômico e nutricional de etnovariedades de cubiu (Solanum sessiliflorum Dunal) da Amazônia. Acta Amazonica, v. 35, n. 4, p. 399-406, 2005. http://dx.doi.org/10.1590/S004459672005000400003

VALDERRAMA, P.; MARANONI, F.; CLEMENTE, E. Efeito do tratamento térmico sobre a atividade de peroxidase (POD) e polifenoloxidase (PPO) em maçã (Mallus comunis). Ciência e Tecnologia de Alimentos, v. 21, n. 3, p. 321-325, 2001.

ZANATTA, C. L.;ZOTARELLI, M. F.; CLEMENTE, E. Peroxidase(POD) e polifenoloxidase (PPO) em polpa de goiaba (Psidium guajava). Ciência e Tecnologia de Alimentos, v. 26, n. 3, p. 705-708, 2006. http://dx.doi.org/10.1590/S0101-20612006000300034 